\title{
Conceptual study on nidana and samprapti of Svetapradara with special reference to Leucorrhoea
}

\author{
Review article
}

\begin{tabular}{|c|}
\hline $\begin{array}{c}\text { Singh Biti }^{1^{*}} \text {, Sundari Hema }{ }^{1} \text {, Katiyar Shipra }{ }^{2}, \text { Srivastava Mallika } \\
\text { Ram Reddy G.P }\end{array}$ \\
\hline $\begin{array}{l}\text { 1. P.G. Scholar, Dept. of Basic Principles, 2. P.G. Scholar, Dept. of Shalya, } \\
\text { 3. Professor \& H.O.D, Department of Basic principles, 4. Reader, Department of Basic } \\
\text { principles, 5. Asst. Professor, Department of Stri and Prasuti Roga, } \\
\text { Sri Venkateswara Ayurvedic College, Tirupati, Andhra Pradesh - } 517507\end{array}$ \\
\hline
\end{tabular}

\begin{abstract}
The reputation of a physician depends upon his skill in diagnosing and treating the patients. Ayurveda has given much importance to nidana (etiology) and samprapti (pathogenesis) as these two are important components of nidana panchaka. Nidana is defined as the fundamental or root cause of a disease and samprapiti is defined as the evolution of an illness. Svetapradara is a condition characterized by white vaginal discharge which is not associated with foul smell, pain, itching, burning sensation etc. thus it can be correlated with Leucorrhoea. It is an annoying complaint of more than $60 \%$ of women seen in gynaecological OPD. The symptoms and treatment of Svetapradara is given in Ayurvedic texts but no where its nidana and samprapti is discussed. This study mainly deals with detailed discussion on nidana and samprapti of Svetapradara. Method - Classical Ayurvedic texts along with the commentaries were carefully studied to compile information about Svetapradara and to evaluate the nidana and samprapti of the disease. Observation - Ayurveda has given more emphasis to nidana and samprapti. It was observed that different ahara, vihara, agantuja, mansika etc karana influences the samprapti of the disease. Result -Vata prakopaka and kapha prakopaka karana are important nidana of Svetapradara and various nidana factors affects the samprapti in different process and accordingly treatment schedule must be adopted.
\end{abstract}

Key words- Svetapradara, Leucorrhoea, nidana, samprapti, nidana panchaka, dosha prakopaka karana.

\section{Introduction}

The health of nation mainly depends on the health of woman because

*Corresponding Author:

\section{Biti Singh,}

P.G. Scholar-Final Year,

S.V.Ayurvedic College,

Kashyapa Girls Hostel, New block,

Room no: 5, SVIMS Road,

Tirupati, Andhra Pradesh

Mobile no: +91-9533132070

Email: Drbitisinghb4@gmail.com the healthy and happy woman lays the first step of a prosperous nation. Any feeling of physical or psychological factor directly affects her attitude and efficacy which adversely affects the family. Hence, the disease which causes physical or psychological concern to a woman should be immediately taken care and equally weighed in medical science.

Svetapradara is a condition characterized by white vaginal discharge not associated with foul smell, pain, burning sensation and itching thus we can 
correlate it with Leucorrhoea(1). The word Svetapradara has not appeared in brihatrayi i.e. Charak, Susruta and Vagbhata Samhita. Commentator Chakrapani and the authors of Sarangadhara Samhita, Bhava Prakash and Yoga Ratnakara have used the word Svetapradara for white vaginal discharge(2). The symptoms and treatment of Svetapradara are given in several ayurvedic texts but no where its nidana and samprapti are discussed. In present era, Svetapradara is quite frequent complaint of more than $60 \%$ of women in gynaecologic clinic. It becomes the necessity of the time to find out an efficacious and harmless therapy to manage this condition, but it is not possible without getting correct knowledge of nidana and samprapti, this is the reason why ayurveda has given more emphasis to nidana and samprapti before treating a disease.

\section{Early work carried out:}

Several studies were done on Svetapradara and its treatment but no where its nidana and samprapti were discussed in detail. This study mainly deals with the detailed discussion on nidana and samprapiti of Svetapradara.

\section{Materials and Methods:}

Classical Ayurvedic texts, commentaries and modern text were thoroughly studied to evaluate the nidana and samprapti of the disease and only nectar part is presented and discussed in the present article.

\section{Nidana:}

Nidana is one of the basic principles in the Ayurvedic line of pathology, hence physician should get acquainted with the nidana, in order to eradicate a disease. So, here the details regarding with the nidana of Svetapradara are discussed:
Charaka, Susruta and Vagbhata have some different opinion regarding the etiology of Yoni vyapad as described in their Samhitas(3,4,5). Among Laghutrayi, both Madhavakara and Bhava Mishra followed Susruta's description. In Sarangadhara samhita only names of Yonivyapad have denoted but not the detailed description(6).

Nidana of yonivyapada according to different Acharyas has shown below:

\begin{tabular}{|l|}
\hline Charaka \\
\hline - \\
- Aithyachara (improper conduct) \\
- Beeja dosha (genetic morbidity) \\
- Daiva (devine factors) \\
\hline
\end{tabular}

\begin{tabular}{|l|}
\hline \multicolumn{2}{|c|}{ Susruta } \\
\hline - Pravrddha linga purshati sevana \\
(excessive indulgence into sex with a \\
man of abnormally developed penis), \\
- Atimaithuna(excessive indulgence into \\
sexual act), \\
- Vyavaya with ruksha, durbala, atibala \\
- Beeja dosha \\
\hline
\end{tabular}

\begin{tabular}{|l|}
\hline \multicolumn{2}{|c|}{ Vagbhata } \\
\hline - Dushtabhojana (vitiated food), \\
visamanga seyana bhrshamaithuna \\
sevana (intercourse in improper \\
position and excessive indulgence into \\
sexual act), \\
- Apadravya sevana (use of artificial \\
things for sexual pleasure) \\
- Dushta Artava \\
- Beeja dosha \\
\hline
\end{tabular}

In brief, all the Acharyas have mentioned four main etiological factors with partial modification. Here these nidana factors are going to be discussed in detail-:

\section{Mithyachara: (Improper conduct)}

The word Achara embodies in itself the entire mode of living. The 
principles of dietetics and regimen including good conduct are essential to maintain positive health. Body and mind constitute the substrata of happiness (positive health) and disease. Improper conduct includes improper maintenance of body, speech, mind etc. in the form of utilization, excessive- utilization and nonutilization of the sense organs and objects concerned. They cause vitiation of mansik and sharirik dosha.

As the important cause of all yonivyapada is vitiation of vata(7). So, the main etiological factor for Svetapradara as described in yonivyapad is vata and the discharge in Svetapradara is of pandura varna which shows predominance of kapha dosha. Vata vitiation occurs due to excessive intake of vata-vardhaka ahara and vihara(8) since they increases ruksha (dry), laghu (light), vishada (clear), sheeta (cold), chala (mobile) etc properties of vata in sarva sharira (all over the body). This vitiated vata takes sthanasamshraya in yoni pradesha, there it vitiates sthanik kapha and expels it excessively in the form of whitish discharge from yoni. So, vata and kapha vitiation are important cause of Svetapradara.

\section{Vata Vitiating Factors:}

Ruksha, katu, tikta, kashaya, laghu etc padarth atisevana, pramita ahara, asatmya ahara, udhalaka, koradushaka, shyamaka, nivara, mudga, masoora, chanaka, kalaya, aadaki etc sevana, balawadvigraha, adhikvyayama, atimaithuna, atiadhwagamana, atijagarana etc all these activities causes vata prakopa(9). Vegavidharana like suppression of mutra, purisha, kshavathu and other natural urges or creating the urges artificially disturb the movement of vata and causes vata aggravation.

\section{Kapha Vitiating Factors:}

Guru, snigdha, picchila, sheeta etc. dravyas, madhura, amla, lavana rasa, anupa mamsa or varija mamsa, dugdha, dadhi, drava padartha, bhavya, piyusha, kharjura, narikeal, ikshu vikara, yavaka, hayanaka, naishedhya etc. atisevana, divaswapana, avyayama, atialasya (10), brimhana, atisukha, sukhasana, sukhashaya, sheeta paricharya during ritusrava kala, shayana between suryodaya and suryasta, samashana, adhyashana etc. are kapha prakopaka ahara vihara.

\section{Apadravya Sevana (usage of artificial things):}

Another more remarkable cause mentioned by Vagbhata is the use of apadravya sevana(11) i.e. abnormal things or artificial things for sexual satisfaction (artificial penis for intercourse) may cause Yonirogas (in immature girl as well as in the mature ones). In this modern era, for different purposes, means like I.U.C.D., diaphragms etc are used which can be considered under this group of etiological factors. The foreign bodies may produce irritation in the mucus membranes of different reproductive organs or may cause infection in the same organ which may lead to yoni rogas like Svetapradara.

\section{Yoni adhavana (unhygienic condition):}

The lack of health education and illiteracy are also the etiological factors of this disorder. Dincharya sevana which includes regular bath and washing of the genital organs are important to maintain the healthy condition of the vulva and vagina.

\section{Manasik karana (psychological factors):} Acharya Sarangadhara has highlighted certain kinds of mental agonies of women originating from the matrimonial relationship which act as predisposing factor for the development of this disease(12). These are divided into two,

(1) Adaksha purusotpanna striroga

(2) Sapatnivihita striroga 
This postulation indirectly points out the involvement of psychological factors which disturbs the equilibrium of doshas, thus promote Strirogas and also the disease Svetapradara. Moreover, mental ups and downs with sorrow, anxiety, exhaustion or constant thinking of sexual objects or others produce excessive secretion from vagina or bartholin's glands.

\section{Artava dusti (menstrual disorder):}

During the menstrual cycle, vata plays a significant role in expelling out the artava through yoni. When this vata gets vitiated alone or associated with other doshas, it causes menstrual abnormalities like nashtartava, kashtartava, anartava, karnini yonivyapada etc. Vitiated vata is the main cause of artava dushti, this vitiated vata takes sthanasamshraya in yoni pradesh, vitiates sthanik kapha and expels out it from yoni.

\section{Beeja dushti (genetic morbidity):}

Abnormality of a portion of beeja responsible for development of yoni during embryonic life in female fetus causes congenital cervical erosion which is one of the cause for Svetapradara.

\section{Daiva (devine factors):}

Among the four causes of Yoniroga, Acharya Charaka has mentioned daiva as one of the causative factor of Yoniroga. Charaka has explained that the effect of what was done during the previous life is known as daiva. It is also seen that where it becomes difficult to find out exact etiology of the diseases, the God has been considered responsible.

\section{Diseases -}

Jananagarbuda, arsha etc. are also responsible for Svetapradara. Jananagarbuda, arsha etc. causes srotas avarodha and vata aggravation. Aggravated vata vitiates sthanik kapha and causes svetasrava from yoni.

\section{Nidana (etiology) and Samprapti (pathogenesis) -}

The above mentioned nidana factors mainly influence vata and kapha doshas, so these factors can be grossly divided into two groups:

1. Vata prakopaka nidana

2. Kapha prakopaka nidana

\section{Vata Prakopaka Nidana(13):}

Ahara:

- Ruksha padarth sevana

- Katu padarth sevana

- Tikta padarth sevana

- Kashaya padarth sevana

- Laghu padarth sevana

- Alpahari

- Shushka shaka

- Shushka mamsa

- Pramita ahara

- Asatmya ahara

- Udhalaka

- Koradushaka

- Shyamaka

- Nivara

- Mudga

- Masoora

- Chanaka

- Kalaya

- Aadaki

- Nishapava

- Ama rasotapatti

- Varatka

- Harenu

- Vishtambhi padarth sevana

- Virudhanna

- Trinadhanya

- Karira

- Tumba

- Kalinga

- Chirbhatta

- Kamalanala

- Shaluka

- Jambava

- Tinduka

- Heena bhojana 
- Shushka bhojana

- Kalaya

- Trishitashana

- Valoor

- Vataka

- Anashana(fasting)

- Vishamashana

- Adhyashana

- Khudhitambupana

\section{Vihara:}

- Ativyayama

- Apatarpana

- Langhana

- Bhagna (fracture)

- Dhatukshaya

- Dukhasana

- Ratrijagarana

- Paraghatana

- Prapatana (falling)

- Vegavidharana

- Atishoka

- Kshobha

- Atibhaya

- Aitvyavaya

- Atyadhyayana

- Pradhavan (running)

- Prapedana (excessive pressure for longer duration)

- Abhighata(injury)

- Plavana

- Pratarana (excessive swimming)

- Bharavahana

- Atyucchabhasana

- Kriyatiyoga

- Gajaticharya

- Rathaticharya

- Pathaticharya

- Asatmya vihara

- Chalana (walking)

- Sahasa (over hasty)

- Vishamopachara

- Vikshepana

- Bhramana

- Chinta (worry)

- Shoka (grief)

- Margavicharana
- Dukhashayya

- Yanatapatana

- Intera uterine contraceptive devices

- Krodha (angry)

- Divaswapana

- Bhaya (fear)

Kala:

- Varsha ritu

- Ashadha/shravana

- Rajah srava kala

- Sheeta kala

- Durdina kala (storm, cloudy etc. environment)

- Sayan kala

- Anna pachana paschata

- Rajonivritti kala

- Jara / vridhhavastha

- Pratah kala/usha kala

Vyadhi:

- Garbhasrava (abortion)

- Garbhapata

- Mudhagarbha (abnormal delivery)

- Mritagarbha (I.U.D.)

- Udarapatana (abdominal surgery)

- Panchakarma vyatikrama

- Doshatisravana

- Raktatisravana

- Rogatikarshana

- Marmabhighata

- Dirgha kalina roga

- Doshavarana

- Doshakshaya(except vata)

\section{Kapha Prakopaka Nidana(14) :}

Ahara:

- Guru, Snigdha, Picchila, Sheeta etc. dravya

- Madhura, Amla, Lavana rasa

- Anupa mamsa / Varija mamsa

- Bhavya

- Piyusha

- Kharjura

- Narikela

- Dugdha (milk) 
- Dadhi (curd)

- Drava padartha

- Ikshu vikara

- Anupa mamsa sevana

- Apakva ghrita sevana

- Atisheetal jala pana

- Yavaka

- Hayanaka

- Nashedhya

- Itakata

- Masha

- Maha Masha

- Godhuma (godhuma)

- Tila/Pishta

- Krishara

- Gaudika

- Vasa

- Navamadhya

- Mridala

- Atyambupana

- Valliphala

- Payasa

- Shringataka

- Kasheruka

- Madhura phala

- Navanna (freshly harvested food article)

- Prithuka

- Mrinala

- Sthulabhakshya

- Shashkuli

- Kilata (solid portion of split milk)

- Morata (thick milk till it becomes thin)

- Aamakshira

- Kurchika (fluid of curd)

- Takra pindaka

- Kadali phala

Kala:

- Hemanta ritu

- Shishira ritu

- Basanta ritu

- Ritukala

- Sheeta kala
- Falguna /chetra

- Ratri kala

- Bhojana sevana kala

- Purvahana

- Ahara sevana in Kapha kala

Vihara:

- Divaswapana (daysleep)

- Avyayama (lack of exercise)

- Atialasya (lazyness)

- Brihana (sedentary food habits)

- Atisukha

- Sukhasana

- Sukhashaya

- Sheeta paricharya during ritusrava kala

- Shayana between suryodaya and suryastamaya

- Samashana (mixed food)

- Adhyashana.

SAMPRAPTI: It can be divided into two categories:

1. Samanya samprapti

2. Vishishtha samprapti

\section{Samanya Samprapti}

Vata prakopaka ahara vihara

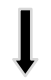

Aggravates vata

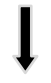

Vishamagni

Sarvadehika/sthanika vata prakopa

Takes sthanasamshraya in yoni pradesha

Ashayapakarsha of kapha dosha and rasa dhatu 
Attipravritti of rasa dhatu and kapha from yoni Pradesha

Svetapradara vyadhi

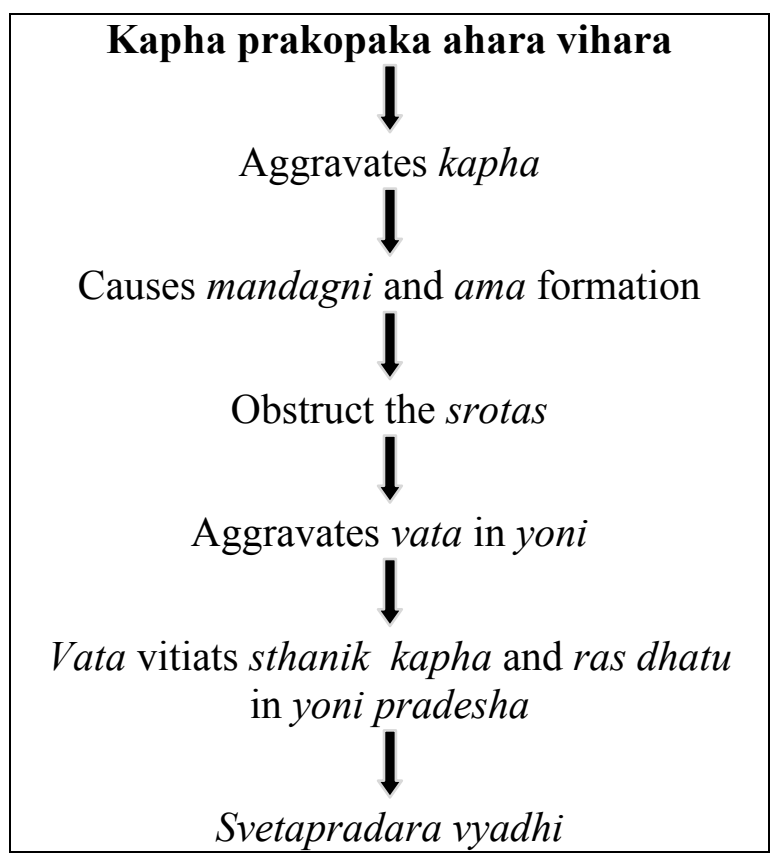

Vishishtha Samprapti (according to different vata prakopak nidana):

\section{Ratrijagarana(late night sleep)(15):}

“Ratro jagarana ruksham” (Ch. Su. 21/50)

\begin{tabular}{|l}
$\begin{array}{l}\text { Creates } \\
\text { rukshata } \longrightarrow\end{array}$ \\
$\begin{array}{l}\text { Increases vata dosha } \\
\text { (kharata, rukshata, } \\
\text { vishadata) }\end{array}$ \\
\hline
\end{tabular}

Ritu Vaishamya(seasonal variations):

According to Charaka, ritu vaishamya has a direct impact on jatharagni. Vitiation of jatharagni produces ama, resulting improper digestion of ingested food. This ama causes srotas avarodha, vitiates vata and rasa dhatu and manifests pathogenesis of the disease.

\section{Vega sandharana (suppression of natural urges):}

It causes vata vitiation, which takes sthanasamshraya in yoni pradesh and vitiates sthanik kapha and expels it out through yoni.

Manasik bhavas (Psychological factors)(16):

Manasik bhavas get disturbed due to chinta, shoka etc. Due to nidana sevana, doshas specially vata gets provoked

Provoked dosha as well as disturbed manasik bhavas hamper the agni

Leads to agni-vaishamya or agni dushti

Rasa-dhatu dushti and dosha prakopa

Doshas get lodged in yoni pradesha

Manifest the disease

According to Charka, chinta (tension) leads to vata and rasavaha srotodushti(17)

"Rasavahini dushyanti chintyana chati chintanata ||"

According to Susruta, manasik bhavas like chinta, shoka, bhaya etc are the etiological factors of ojakshaya i.e. immunity gets weak, which leads a person to become more susceptible or prone to get diseased.

Other vata prakopaka nidana:

\begin{tabular}{|l|}
\hline Injury during child birth, asamyaka \\
paricharya during rajaswala kala, \\
garbhasrava kala- \\
$\downarrow$ \\
Vata prakopa
\end{tabular}




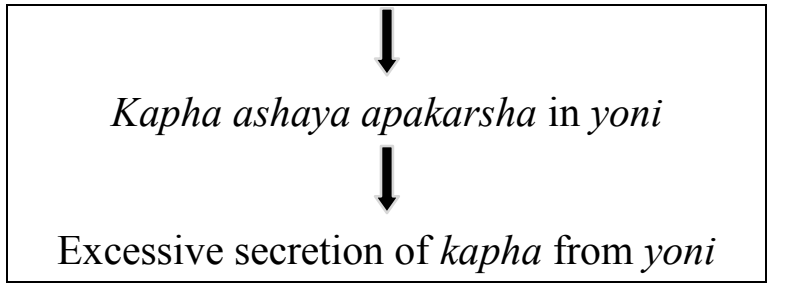

Intra uterine devices (apadavya prayoga):
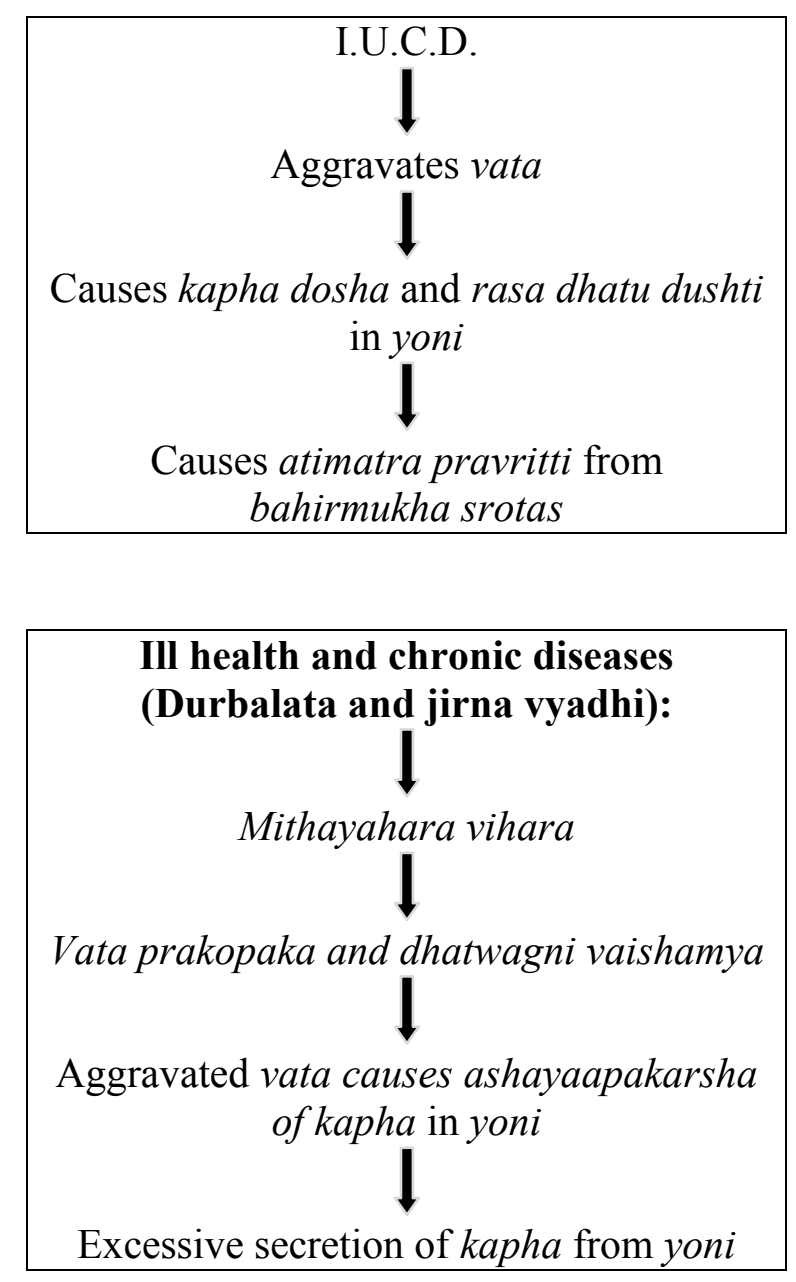

\section{Acquired retroverted uterus / Prolapsed uterus: (antarmukhi / mahayoni)}

Due to mamsa dhatu vaishamy(kshaya)

\section{Vata aggravates}

Causes kapha dosha and rasa dhatu dushti in yoni
Causes atimatra pravritti from srotas

Mucus Polyp (karnini yonivyapada):

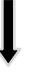

Karninika

Causes srotas avarodha

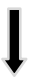

Vata aggravates

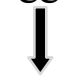

Causes kapha and rasa dhatu vitiation

Expels kapha and rasa dhatu out from yoni

Vishishtha Samprapti (according to different kapha prakopak nidana):

\section{Samashana, Vishamashana, Atimatra bhojana}

Indigestion of ingested food leading to production of ama

Ama causes srotas avarodha

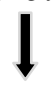

Vitiates kapha dosha and rasa dhatu<smiles>C1CC1</smiles>

Circulates throughout the body through<smiles></smiles>

Sthana samshraya at khavaigunya in yoni pradesha

Expulsion of kapha and rasa dhatu from yoni

The intake of the improper quantity of diet is the atimatra bhojana, intake of pathya and apathya ahara at a time is 
samshana and the intake of diet untimely is vishamashana, these dietary habits causes agni mandhya and produces ama, simultaneously aggravates kapha and after getting localized in the female genital organs it results into Svetapradara.

\section{Ritu}

vaishamya(seasonal variations)(18):

According to Charaka, ritu vaishamya has a direct impact on jatharagni (C.Ci.15/42-44). Vitiation of jatharagni produces ama, resulting improper digestion of ingested food. This ama causes srotas avarodha vitiates vata, kapha and rasa dhatu and manifests pathogenesis for the disease.

\section{Atimatra guru-sheeta-madhura ahara :}

The dravyas which are brimhaniya in action are snigdha, madhura, guru and kledakara (slimy). Under such dravyas navanna (newly harvested rice), navasava and aristas, meat of anupa (aquatic) animals, cow's milk and its different preparation, varieties of sugar derivatives etc. also fall under this group.

As mentioned by Acharya Charaka -

"Sarvada sarva bhavanam samanya vriddhi karanam $\| ”(C h . S u .1 / 44)$

With excessive intake of guru, sheeta and madhura ahara

Dosha gets aggravated due to the principle "sama-guna vriddhi"

Aggravated kapha follow the same vicious cycle of pathogenesis, as mentioned above to manifest the disease.

\section{Dadhi and amaksheer -}

Both have abhishayandi property, causing the srotoavarodh (obstruction) and kapha vriddhi. The abhisyandi (channel blocking substances) as clearly explained by Susruta are those which possess the capacity to produce kleda in the doshas, dhatus, malas and srotas by the pichhila and guru gunas, it obstructs the srotas (channels), dhatu poshana (nourishment) hampered. Due to its guru guna it increases the kapha as well as the kleda. So, in the Svetapradara the excessive consumption of abhisyandi dravya enhances the vaginal discharge and thereby causes other signs and symptoms.

Jalaja / Anupa mamsa sevana - Having kleda guna, increases the klinnata in srotoas.

Ritu kala - Kapha dhatu vriddhi causes excessive secretion from yoni marga.

\section{Chronic cervicitis (kaphaja yonivyapada):}

\begin{tabular}{c}
\hline Pandura and picchila srava \\
Excessive rasa dhatu kshaya and kapha \\
kshaya \\
Causes vata aggravation in yoni pradesh \\
Svetapradara
\end{tabular}

Samprapti according to vata and kapha prakopak nidana:

Snana with atisheetal jala:

Sheetala jala
Vitiates vata and kapha dosha
Takes sthanasamshraya in yoni pradesh
Vitiates sthanik dosha and dhatu in yoni
pradesha
Vriddha vata expels out


Doshas and dhayu (kapha and rasa dhatu) through yoni

Giving rise the disease

\section{SAMPRAPTI (pathogenesis):}

"Dosha eva hi sarvesam roganam eka karanam" (19)

Several etiological factors contributing to disease formation and the vitiation of doshas invade and disturb the body every now and then. Some of them can be avoided by adopting proper precautionary measures while some factors like kala (time), karma (deeds), desha (place) etc. are mostly unavoidable. If the resistance power of the body against the disease is functioning well, then only, the body can fight against the etiological factors successfully, thereby maintaining sound health.

But if the etiological factors are stronger than the power of resistance of the body then those factors after vitiating dosha and dushya bring the process of disease inside the body.

The involvement of all doshas is the most prime event as far as the manifestation of the disease is concerned. This statement is strongly supported by Vagbhata's verse.

"Savervesameva Roganam nidanam kupitaa malah" (20)

\section{Samchaya vastha (stage of accumulation):}

In all yonirogas, all these changes take place before the occurrence of the particular disease. Acharya Susruta has very clearly mentioned that a man with abnormal genitalia when indulges into coitus with a very young girl or women in an undesired and un-comfortable position then the vata becomes vitiated and this vitiated vata starts getting sanchaya in the garbhasaya with the help of other two doshas- pitta and kapha to produce yonivyapad.

Regarding the Yonivyapada, it has been narrated clearly that kapha will not vitiate without the involvement of vata dosha. The practice of vata provoking factors like ruksha (dry), laghu (light), sheeta (cold) etc. food articles vitiates vata and makes jatharagni irregular eventually formed undigested materials (ama) commence to accumulated (sanchaya) in the amashaya. This phase of pathological change in the body can be commented here as the first stage of kriyakala i.e. sanchayakala.

\section{Prakopavastha (stage of aggravation):}

After the accumulation (sanchaya) of more and more of this kind of ama, in its own asaya, the provocation (unmargagamita) of it occurs with specific prakopaka factors in the prakopavastha. During this stage, patient complaints of annadwesha(anorexia), angamarda (lethargyness), alasya (lassitude) etc.

\section{Prasaravastha (stage of spreading):}

Thus, overwhelmed dushta ama then circulates all over the body through rasavaha srotas by the motive force of the body i.e. vyana vayu in the prasaravastha. Circulating ama causes srotas avarodha, which causes excessive vata aggravation and rasavaha srotas dushti.

\section{Sthanasamshrayavastha (stage of pordromal symptoms):}

Meanwhile by the activities and unwholesome food articles, over indulgence in sexual activities etc the vitiated vata dwelling at trayavartayoni (sthanasamshraya) and produces the khavaigunya in the artavavaha strotas. Due to agni vaishamya and srotas avarodha, kapha dosha and rasa dhatu are formed excessively in yoni pradesha. 
Vyaktavastha (stage of disease):

In the fifth stage of kriyakala the expression of the pathology occurs. Here, this happens in the form of appearance of white discharge through vagina by the activity of expulsion of apana vayu, as the cardinal symptom with profuse appearance of all symptoms like yonisrava, yonipicchilata or yoni sula, slight yonikandu etc in the vyaktavastha.

\section{Bhedavastha (stage of accumulation):}

The dirghakalina anubandhatva i.e. chronic nature of this ailment can be considered as the sixth avastha of kriyakala i.e. the bhedavastha. Now it becomes clear that in this disease process mainly the sthanik kapha and rasa dhatu plays a very important role whereas vata dosha takes as initiative for it.

The samprapti of Svetapradara can be summarized as follows:

\begin{tabular}{|c|c|}
\hline - Dosha & Vata and Kapha \\
\hline - Dusya & Rasa Dhatu \\
\hline - Adhisthana & $\begin{array}{l}\text { Yoni, } \\
\text { Garbhashaya }\end{array}$ \\
\hline - Udbhava Stana & Amashaya \\
\hline - Srotas & Rasavaha Srotas \\
\hline $\begin{array}{l}\text { - Srotodushti } \\
\text { Prakara }\end{array}$ & Atipravritti \\
\hline - Vyaktha Stana & Yoni \\
\hline - Rogamarga & Abhyantara \\
\hline $\begin{array}{l}\text { Pratyatma } \\
\text { Lakshana }\end{array}$ & $\begin{array}{l}\text { Atipandura } \\
\text { srava,Yoni } \\
\text { klinnata,Yoni } \\
\text { shitalata }\end{array}$ \\
\hline
\end{tabular}

\section{Discussion and conclusion:}

Ayurveda is not a drug to disease regimen science. Ayurveda has given more emphasis to nidana and samprapti as samprapti vighatana is chikitsa. In Ayurveda treatment mainly depends on nidana and samprapti. Vata prakopaka and kapha prakopaka karana are important nidana of Svetapradara and various nidana factors affects the samprapti in different stages of kriyakala. According to different nidana, samprapti also changes. If physician understands the samprapti in a proper way he will never fail in the management of Svetapradara.

\section{References:}

1. Dutta D.C., Text Book Of Gynecology, New Central Book Agency Ltd., 5ed, 2009, 524p.

2. Charaka Samhita Chikitsa 30/116 Chakrapani Tika, Bhavaprakasha Chikitsa 70/87, Yogaratnakar with "Vaidhyaprabha" Hindi Commentary, Varanasi, Chaukhambha Bharti Akadamy, 3ed, 2011, 808p.

3. Shastri Kashi Natha, Charaka Samhita, Varanasi, Chaukhambha Bharti Academy, 2006, 814p.

4. Shastri Ambika Datta Shastri, Susruta Samhita, Delhi, Chaukhambha Sanskrita Academy, 2006, 156p.

5. Gupta Atridev, Astanga Hridaya, Varanasi, Chaukhambha Publication 3ed, 2009, 775p.

6. Parashar Radha Krishana, Sharagadhara Samhita, Nagapur, Shri Vaidhya Nath Ayurveda Bhavana Ltd., 3ed, 1984, 166p.

7. Shastri Kashi Natha, Dr.Gorakhanath Chaturvedi, Charaka Samhita, Varanasi, Chaukhambha Bharti Akadamy, 2006, 858p.

8. Shastri Kashi Natha, Dr.Gorakhanath Chaturvedi, Charaka Samhita, Varanasi, Chaukhambha Bharti Academy, 2005, 15p.

9. Shastri Ambika Datta, Susruta Samhita, Delhi, Chaukhambha Sanskrita Academy, 2006, 91p.

10. Shastri Ambika Datta, Susruta Samhita, Delhi, Chaukhambha Sanskrita Academy, 2006, 91p.

11. Gupta Atridev, Astanga Hridaya, Varanasi, Chaukhambha Publication 3ed, 2009, 775p. 
12. Parashar Radha Krishana, Sharagadhara Samhita, Nagapur, Shri Vaidhya Nath Ayurveda Bhavana Ltd., 3ed, 1984, 168p.

13. Dhyani Shiva Charana, Nidana Panchaka, Varanasi, Chaukhambha Surabharti Publication 1st, 2010, 29p.

14. Dhyani Shiva Charana, Nidana Panchaka, Varanasi, Chaukhambha Surabharti Publication 1st, 2010, 31p.

15. Shastri Kashi Natha, Gorakhanath Chaturvedi, Charaka Samhita, Varanasi, Chaukhambha Bharti Academy, 2005, 420p.

16. Kashi Natha Shastri, Gorakhanath Chaturvedi, Charaka Samhita,
Varanasi, Chaukhambha Bharti Academy, 2005, 713p.

17. Kashi Natha Shastri, Gorakhanath Chaturvedi, Charaka Samhita, Varanasi, Chaukhambha Bharti Academy, 2005, 713p.

18. Kashi Natha Shastri, Gorakhanath Chaturvedi, Charaka Samhita, Varanasi, Chaukhambha Bharti Akadamy, 2006, 460p.

19. Gupta Atridev, Astanga Hridaya, Varanasi, Chaukhambha Publication 3ed, 2009, 124p.

20. Gupta Atridev, Astanga Hridaya, Varanasi, Chaukhambha Publication 3ed, 2009, 296p. 